\title{
1 Predator chemical cue effects on the diel feeding behaviour of marine protists
}

2 Anna Arias $^{1 *}$, Erik Selander ${ }^{2}$, Enric Saiz $^{1}$, Albert Calbet ${ }^{1}$

$3{ }^{1}$ Institut de Ciències del Mar (ICM-CSIC), Passeig Marítim de la Barceloneta 37-49,

408003 Barcelona, Spain

$5 \quad{ }^{2}$ Department of Marine Sciences, University of Gothenburg, Box 461, SE-450 30

6 Göteborg, Sweden

7

$8 *$ arias@icm.csic.es 


\section{Abstract}

10 We have assessed the effect of copepod chemical cues on the diel feeding rhythms of

11 heterotrophic and mixotrophic marine protists. All phagotrophic protists studied

12 exhibited relatively high diurnal feeding rates. The magnitude of the diel feeding

13 rhythm, expressed as the quotient of day and night ingestion rates, was inversely

14 related to the time that phagotrophic protists were maintained in the laboratory in an

15 environment without predators. In the case of the recently isolated ciliate Strombidium

16 arenicola, the rhythm was lost after a few months. When challenged with chemical

17 alarm signals (copepodamides) from the copepod Calanus finmarchicus at realistic

18 concentrations (0.6-6 pM), S. arenicola partially re-established diurnal feeding.

19 Conversely, the amplitude of the diel feeding rhythm for the ciliate Mesodinium

20 rubrum was not affected by copepodamides, although the $24 \mathrm{~h}$ integrated food intake

21 increased by approximately 23\%. For the dinoflagellates Gyrodinium dominans and

22 Karlodinium armiger, copepodamides significantly reduced the amplitude of their diel

23 feeding rhythms; significant positive effects on total daily ingestion were only

24 observed in G. dominans. Finally, the dinoflagellate Oxyrrhis marina, isolated $>20$

25 years ago, showed inconsistent responses to copepodamides, except for an average

$266 \%$ increase in its total ingestion over $24 \mathrm{~h}$. Our results demonstrate that the predation

27 risk by copepods effects the diel feeding rhythm of marine protists and suggests a

28 species-specific response to predation threats.

29 Keywords: copepodamide, feeding rhythms, grazing, copepods, microzooplankton,

30 dinoflagellate, ciliate 
33 Microzooplankton are key components of marine planktonic food webs, representing

34 a crucial trophic link between primary producers and mesozooplankton [1,2]. Despite

35 their relevance, some key aspects of microzooplankton trophic behaviour and their

36 impacts on planktonic food webs are still unclear. This is the case, for instance, for

37 diel feeding rhythms. While laboratory-based studies with different protist species

38 have repeatedly reported higher ingestion rates during the day-time (hereafter referred

39 to as diurnal feeding) than during the night-time (e.g., [3-7]), the reasons for the

40 existence of these rhythms are not yet well understood. Arias et al. [8] proposed that

41 the diurnal feeding rhythm of marine protists could have evolved as a strategy to

42 minimize the risk of predation, given that their main predators, copepods, typically

43 exhibit nocturnal feeding (Fig. 1). Feeding by free-living protists involves motility,

44 therefore increasing conspicuousness and encounter rates with predators [9]. Thus, an

45 optimal microzooplankton might have developed an inverted feeding rhythm to that

46 of its predator as a compromise between gathering food and avoiding predation [10-

47 12]. Indeed, a predation-avoidance strategy has already been proposed to drive diel

48 rhythms in larger zooplankton like copepods [13, 14], but such behavioural responses

49 to predation have not yet been demonstrated in microzooplankton.

50 Copepods release different types of chemical cues in the surrounding waters [15] that

51 induce defensive traits in their prey (Fig. 1). The most well-known are copepodamides

52 [16], which induce toxin production in the dinoflagellate Alexandrium minutum [16]

53 and in the diatom Pseudo-nitzschia seriata [17], a reduction of the chain length in the

54 diatom Skeletonema marinoi [17] and an increase in the bioluminescence capacity in 
various dinoflagellate species $[18,19]$. Nevertheless, the effect of copepodamides on

56 the feeding activity of marine phagotrophic protists remains unexplored.

57 Within this framework, we aimed to evaluate the effects of predation risk on the diel

58 feeding rhythms of marine protists. We first explored how the time kept in predator-

59 free cultures affects the presence of diel feeding rhythms in several species of

60 heterotrophic and mixotrophic protists. Then, we simulated the presence of copepod

61 predators by using copepodamides and experimentally investigated the effects of the

62 threat of predation (mediated by chemical cues) on the rhythmic feeding activity of

63 these grazer protists.

\section{Materials and methods}

66

(a) Prey and grazer cultures

67

We used the heterotrophic ciliate Strombidium arenicola (strain ICM-ZOO-SA1-

2017), the mixotrophic ciliate Mesodinium rubrum (strain DK-2009), the heterotrophic dinoflagellates Gyrodinium dominans (strain ICM-ZOO-GD1-2011) and Oxyrrhis marina (strain ICM-ZOO-OM1-1995), and the mixotrophic dinoflagellate Karlodinium armiger (strain ICM-ZOO-KA1-2013) as grazers in our experiments. All strains were isolated from the NW Mediterranean Sea between 1995 and 2017, except for M. rubrum, which was isolated from Danish waters in 2009 (Dr. Per J. Hansen, University of Copenhagen). Stock cultures were kept in a cold room at $19 \pm 1^{\circ} \mathrm{C}$ and grown on 38 PSU autoclaved filtered seawater enriched with metals (1 $\mathrm{mL}$ metal stock per litre; [20]), provided with irradiance of $90 \mu \mathrm{E} \mathrm{m} \mathrm{m}^{-2} \mathrm{~s}^{-1}$ (white 
salina (strain K-0294) daily, except for M. rubrum, which was fed the cryptophyte

Teleaulax amphioxeia (strain K-1837) every other day. $R$. salina was isolated from

danish waters and T. amphioxeia was isolated from the Elsinore Harbour. Batch cultures of $R$. salina, provided with gentle air bubbling, were grown in $\mathrm{f} / 2$ medium and diluted daily to maintain exponential growth. T. amphioxeia was grown under the same conditions but without air supply.

We first analysed the permanence of diel feeding rhythms in the target species. Two replicate experiments were conducted per each species, except for the recently isolated S. arenicola. For this species, four experiments were carried out, corresponding to 6 (October 2017), 10 (February 2018), 19 (November 2018) and 20 (December 2018) months after the time when it was isolated (April 2017).

91 Grazing experiments were conducted under saturated prey conditions, specific to each studied species (Table 1; functional response data from Arias, unpublished; Calbet et al. [21]; Martínez, unpublished; Fig. S1). In the experiments, R. salina was used as prey for all grazers and it was offered in stationary phase to avoid day/night size differences (see Arias et al. [3]). Prior to the experiments, the grazers were starved for $48 \mathrm{~h}$ to ensure that previously ingested prey-cells were completely processed prior to the experiment [3, 22-24]. In the experiment setup, two suspensions were prepared: one only with the prey to serve as a control for prey growth and another with the same concentration of prey and the desired number of grazers. The grazing incubations were conducted in $72 \mathrm{ml}$ polyethylene culture flasks (three replicated experimental 
and control flasks on each), which were incubated on a plankton wheel (0.2 r.p.m)

102 from the beginning (9:00 a.m.) until the end of the day (7 p.m.), at $19 \pm 1{ }^{\circ} \mathrm{C}$, and 90

$103 \mu \mathrm{E} \mathrm{m}^{-2} \mathrm{~s}^{-1}$ irradiation; the experiment was then repeated for the night-time incubation

104 under complete darkness (from 7 p.m. to 9 a.m.). Concentrations of prey and grazers

105 were determined with a Beckman Coulter Multisizer III (100- $\mu$ m aperture tube) at the 106 beginning and the end of each incubation period.

107 (c) Effects of copepodamides on protist feeding behaviour

108 Copepodamides are surface-active and degrade over time in seawater, leading to an

109 actual concentration (i.e., effective concentration) lower than the initially added

110 concentration (i.e., nominal concentration) [25, 26]. For this reason, before

111 undergoing grazing experiments we carried out a preliminary test to assess the

112 effective concentrations of copepodamides at the starting point and during the

113 experiments, and also to determine the most appropriate concentrations to be used

114 (Fig. S2; see Supplementary Materials for the determination of effective

115 concentrations methodology).

116 To test the effect of predation risk on the rhythmic feeding behaviour and the total

117 daily ingestion (i.e., day and night sum) of the target grazers, we carried out diel

118 feeding experiments using two copepodamide treatments, 1.4 and $18 \mathrm{pM}$ initial

119 concentrations (average effective concentrations during incubations of 0.6 and $6 \mathrm{pM}$,

120 respectively; Table 2). Copepodamides were extracted from freeze-dried Calanus

121 finmarchicus through a series of chemical separation steps (see Selander et al. [16] for

122 further details). The lowest concentration used in our study was within the natural

123 range of copepodamide concentrations $(0.4-2 \mathrm{pM} ;[17,26])$. As concentrations may

124 vary widely depending on the density of copepods or the proximity to the source, we 

cover this range.

127 The experimental methodology used for the feeding incubations was the same as the

128 one described in the previous section (Diel grazing rhythm experiments), but in this

129 case, the control treatments had methanol added at the highest concentration used as

130 diluent for the copepodamide solution. Fresh copepodamide doses were prepared each

131 day and night. We conducted the experiments twice to ensure data robustness. The

132 experiments with $S$. arenicola were conducted after 19 and 20 months of laboratory

133 cultivation, when no diel feeding rhythm was apparent.

(d) Statistical analysis

135 To explore the existence of significant differences of grazers ingestion rates between

136 day-time and night-time, we applied t-tests comparing the results obtained from the

137 triplicate bottles of each treatment on the day-time and the night-time. We also 138 applied t-tests to determine the effect of copepodamides on the diel feeding rhythm of

139 the grazers in relation to the rhythm exhibited when no chemical cues were added.

\section{3. Results}

(a) Laboratory time-dependent diel feeding rhythm

143 For the whole group of protists studied, there was a negative relationship between the

144 time from isolation and the amplitude of the diel feeding rhythm, defined as the

145 quotient day/night ingestion rates (Fig. 2). In general, the magnitude of the rhythm

146 ranged from 1.5 (O. marina) to 3 times (S. arenicola and G. dominans) higher 
ingestion rates during the day than during the night (Fig. 2). All species showed significant differences between day and night ingestions ( $p<0.01$ in all cases). The

149 rhythm was still detectable after 22 years of laboratory cultivation in O. marina.

150 Conversely, the diel feeding rhythm of the recently isolated ciliate $S$. arenicola

151 decreased more rapidly over time in a predator-free laboratory environment (Fig. 3a);

152 ingestion rates during day-time were 3 times significantly higher than during night-time 153 when first measured (t-test, $p<0.001$; October 2017), but these diel differences 154 completely disappeared after 19 months of maintenance in the laboratory (November 155 2018; t-test, $p>0.05$; Fig. 3a).

156 (b) Effect of predation risk on the diel feeding rhythm of laboratory-cultured protists

157 When exposed to grazer cues, under both concentrations of copepodamides, the diel

158 feeding rhythm of $S$. arenicola was partially reinstated (27-45\% recovery relative to

159 the treatment without copepodamides; t-test, $p<0.05$ in all treatments; Fig. 3b; see

160 Table S1 for actual day and night ingestion rates). This enhancement of the diel

161 feeding rhythm did not consistently affect total daily ingestion (Table 3). The day and

162 night ingestion rate quotient of the other ciliate species, $M$. rubrum, also showed a

163 positive response to copepodamides (Fig. 4a), but it was weak (3-10\% increase) and

164 not significant (t-test, $p>0.05$ in all cases). However, in this case, the total daily 165 ingestion increased by $23 \%$, on average (Table 3 ).

166 Dinoflagellates were less consistent and showed variable responses to

167 copepodamides. The amplitude of the diel feeding rhythm of $G$. dominans decreased

168 by approximately $13 \%$ and $8 \%$ in copepodamide exposures of 0.6 and $6 \mathrm{pM}$,

169 respectively (t-test, $\mathrm{p}<0.05$ in all cases; Fig. 4b; Table S1). Total ingestion over $24 \mathrm{~h}$, 
on the other hand, increased by $10 \%$, on average (Table 3 ). K. armiger also

171 significantly reduced the feeding rhythm in a dose-dependent manner, $22 \%$ in $0.6 \mathrm{pM}$

172 and $46 \%$ in 6 pM copepodamide exposure (t-test, $p<0.05$ in all treatments; Fig. 4c;

173 Table S1). The total daily ingestion of this species was only significantly different

174 from the control in the higher $(6 \mathrm{pM})$ copepodamide exposure in one of the two

175 replicated experiments (Table 3 ). Finally, the $O$. marina response to copepodamides

176 was inconsistent (Fig. 4d; Table S1); in the first experiment, the amplitude of the

177 feeding rhythm decreased 2-23\% when exposed to copepodamides (t-test, $p<0.05$ for

178 the lowest copepodamide concentration), but in the second experiment, it increased

179 significantly by $8 \%-12 \%$ (t-test, $p<0.05$ in all treatments). The effects of

180 copepodamides on total ingestion (over $24 \mathrm{~h}$ ) on this species ranged from non-

181 significant to a $11 \%$ reduction (Table 3 ).

\section{Discussion}

185 In this study, we provided the first evidence of a modulation in the diel feeding

186 behaviour of marine protist grazers in response to predator chemical cues. Moreover,

187 we also showed that copepodamides have the potential to reinstate the diel feeding

188 rhythm in a ciliate, whose inherent rhythmic behaviour was lost when reared under

189 predator-free laboratory conditions. 

ciliates

193 The absence of predators under laboratory rearing conditions appeared to be a

194 probable factor inducing the loss of feeding rhythm in our strain of the ciliate $S$.

195 arenicola. Similarly, the other protists studied also seemed to show a time-dependent 196 weakening of their diel feeding rhythm, although at a much longer scale (years).

197 Similar results were observed by Arias et al. [3] when comparing the feeding rhythm 198 amplitude of two strains of the dinoflagellate O. marina isolated in different years 199 (1995 and 2016), with the newest isolated strain showing the highest amplitude 200 feeding rhythm, although we cannot exclude inter-strain variability.

201 The fading of a diel feeding rhythm in the absence of predators in the laboratory has 202 already been documented for marine copepods [27], and the presence of fish has also 203 been reported to sharply enhance their diel feeding cycle [28], although the role of 204 chemical cues alone might not be so clear $[29,30]$. However, the physical presence of 205 fish can induce changes in some behavioural and morphological traits of copepods.

206 For example, fish presence has been reported to induce diapause in copepods from 207 freshwater ecosystems [31], as well as mating behaviour alterations [32], changes in 208 body and clutch sizes [33], and variations in the pigmentation level used as 209 photoprotection [34]. Other groups, such as freshwater rotifers and cladoceran, 210 however, are more prone to respond to predator chemical cues. For instance,

211 freshwater water fleas develop behavioural (e.g., [35]), morphological (e.g., [36]) and 212 life-history trait (e.g., [37]) responses as anti-predator defences to predator exudates 213 or physical presence. Additionally, rotifers display morphological responses, 214 involving the development and elongation of spines and appendages with the 
consequent increment in body size, to kairomones produced by copepods [43].

216 Similar responses have been described in dinoflagellate defensive mechanisms as a

217 response to copepod chemical alarm signals. Lindström et al. [18] reported an

218 increase in the total bioluminescence capacity of the long-term laboratory-cultivated

219 (9-14 years) dinoflagellates Lingulodinium polyedra and Alexandrium tamarense

220 when exposed to copepodamide dose treatments. Similarly, the production of toxic

221 secondary metabolites in dinoflagellates (described as another defence mechanism

222 against predators) is also reduced when organisms are cultivated in the laboratory

223 [18], but it is also restored under exposure to waterborne copepod cues [39] and

224 copepodamides [16].

225 The recovery of the diel feeding rhythm in S. arenicola when exposed to

226 copepodamides resulted in a significant decrease in ingestion rates during the night

227 (see Table S1), supporting the hypothesis of a relationship between feeding rhythm

228 and threat of predation. The effect of predation threat also translated into the decrease

229 in the total ingestion rate observed in this species. In contrast, in Mesodinium rubrum,

230 feeding rhythms were not significantly affected, and the total daily ingestion rate

231 increased when exposed to copepodamides. Therefore, the two ciliates studied

232 responded differently to predator chemical cues. The difference may have resulted

233 from behavioural differences between species. It is known that predation risk to

234 ciliates is determined by their escape ability $[9,40]$. In our study, S. arenicola, such as

235 other Strombidium species, was expected to have a relatively low escape ability [40].

236 Consequently, at night, when copepods ascent to surface layers and may overlap with

237 ciliates, this species may benefit from reduced nocturnal feeding (which implies lower

238 swimming activity) to reduce conspicuousness and hence safeguard its survival.

239 Conversely, when predators are absent, continuous feeding seems to be more 
advantageous. $M$. rubrum, on the other hand, exhibited a very different swimming

241 behaviour based on a combination of long motionless periods interspersed with

242 shorter periods of quick jumps. Previous studies have highlighted the effective escape

243 response of $M$. rubrum when surrounded by copepods, which substantially reduces its

244 vulnerability to predator mortality in comparison to that of other planktonic ciliates

245 [41]. In fact, M. rubrum is characterized by an extremely high swimming speed for a

246 protist (at over $5 \mathrm{~mm} \mathrm{~s}^{-1}$ and up to $8.5 \mathrm{~mm} \mathrm{~s}^{-1}$, at least momentarily; [42]),

247 approximately an order of magnitude faster than most other ciliates [43]. Therefore,

248 the non-significant response of M. rubrum to copepodamides may be based on its high

249 capability to escape from predators, which may make it less necessary for this species 250 to largely modify its diel feeding behaviour.

(b) Contrasting responses of dinoflagellates to copepodamides

253 The general response of dinoflagellates to copepodamide exposure was a decrease in

254 the amplitude of the diel feeding rhythm, except for $O$. marina, which did not present

255 a clear response. Regarding the heterotrophs $G$. dominans and O. marina, the

256 variation in the amplitude of the diel feeding rhythm was caused by an unequal

257 increase in both diurnal and nocturnal feeding and a consequent significant increase in 258 total daily ingestion rates (Table S1). In contrast to ciliates, dinoflagellates are not 259 able to escape from copepods due to their limited swimming capacity [40]. Thus, we

260 believe that when threatened by predation, heterotrophic dinoflagellates may increase 261 total daily prey uptake, independent of a dictated diel feeding rhythm, to maximize

262 their energy intake for reproduction and ensure the rapid growth of the population, 263 guaranteeing their survival. In environments with high predation risks, faster growth 
264 has been suggested as an adaptive response to outgrow the hunting impact of the

265 predator in the population [44]. An increase in the prey growth rate as a defence

266 response to predation risk has also been described in water fleas [45, 46].

267 In the particular case of $O$. marina, the ambiguous results of the effect of predation risk

268 on the diel feeding rhythm (increasing versus decreasing its amplitude) could also be 269 associated with the habitat of the species. This dinoflagellate typically thrives in 270 intertidal pools, and shallow waters [47-49], which might be environments where diel 271 migration is probably not as relevant than in open, deeper aquatic domains. Hence, this 272 dinoflagellate may not have experienced the necessity to evolve predator-defence 273 mechanisms associated to diel rhythms.

274 Both $K$. armiger and G. dominans showed a reduction in the magnitude of feeding 275 rhythms when exposed to copepodamides. However, in contrast to G. dominans, $K$. 276 armiger did not consistently increase its total ingestion rate. The pattern observed in $K$. 277 armiger with a decrease in diurnal feeding and an increase in nocturnal feeding might 278 be partially related to the grazer photosynthetic activity. This dinoflagellate presents 279 higher growth rates when feeding on microalgal prey (Li et al., 1999; Berge et al., $2802008 \mathrm{a} ; 2012$ ) and, under saturated prey conditions, phagotrophy represents the main 281 source of carbon (Berge, 2016); however, when threaten by predators, the strategy of $282 K$. armiger might be based on boosting photosynthetic activity during the day and 283 devote night hours to feed when they have the possibility to catch higher size prey (no 284 upper prey size limit has been described for this dinoflagellate), by which they adquire 285 essential growth factors (Berge et al., 2008). Nevertheless, we consider that this 286 particular behaviour might be also related to the capability of $K$. armiger to produce 287 karmitoxin, a toxin that can cause the rapid (within minutes; [50]) immobilization and 
mortality of copepods [51]. Toxin production in dinoflagellates has been reported to be

289 induced by the presence of copepods and their chemical signals $[52,53]$ and, recently, 290 by copepodamides [16]. Several dinoflagellates have efficient grazer deterrent traits 291 that alone probably allow them to co-exist with copepods $[19,54]$.

292 In this study we have demonstrated that the risk of predation by copepods can 293 strongly affect the diel feeding rhythms of micrograzers, hence becoming an 294 important trigger of such rhythmicity. However, other triggers may exist and, 295 moreover, other factors are already known to modify this rhythmic activity. For 296 instance, the feeding behaviour of marine protists is widely modified by prey 297 availability, with the major differences between day and night ingestion rates under 298 saturated food conditions, and poorly marked or inexistent rhythms under food 299 limitation [3]. Moreover, in natural communities, the feeding patterns of marine 300 protists have been suggested to vary according to prey and grazers species 301 composition [55].

302 Finally, diel feeding rhythms in marine protists become an important event to 303 consider when addressing grazing approaches in situ [56]. Not talking into account 304 this rhythmic activity may lead to considerable vias or incorrect interpretation of the 305 results as it involves important differences depending on the phase of the diel cycle.

\section{Final remarks}

In this study, we have shown that predation threat can affect the feeding behaviour of

309 several heterotrophic and mixotrophic protist species. The overall pattern of a gradual decrease in the diel feeding rhythm in long-term predator-free laboratory cultures may 
311 indicate, the importance of predation risk in modulating feeding behaviour. However,

312 given we only have the whole time-course of one strain of one species and that other

313 evidences may be slightly marginal we cannot disregard other factors, such us strain

314 variability and loss of diversity, taking place. Moreover, the diversity of the

315 responses to copepodamides as a proxy for predation threat by copepods, their main

316 natural predator, suggests a species-specific response, depending on the physiological

317 (e.g., deterrent production), behavioural (e.g., hydrodynamic conspicuousness and

318 escape ability) and ecological (e.g., habitat) traits of the grazers. Nonetheless, we

319 should consider that the risk of predation might not be the only trigger of the diel

320 feeding rhythm in all marine protists.

323 Supplementary information. Supplementary information is available online at

324 Microbial Ecology and includes (a) the functional response of the ciliate Strombidium

325 arenicola, (b) a detailed explanation of the methodological process conducted to

326 determine copepodamide effective concentrations and the resultant plot of

327 copepodamide effective concentration throughout the incubation, and (3) a table

328 containing day-time and night-time ingestion rates per grazer species studied in each

329 experiment.

331 Acknowledgements. We are grateful to all members of the research group Signals in 332 the Sea for collaborating from the University of Gothenburg, with special thanks to 333 Andrew Prevett for technical assistance and valuable help during laboratory work. We 334 also want to thank Jan for the illustrations. 
336 Funding. This work was supported by the FERMI project (CGL2014-59227-R;

337 MINECO/AEI/FEDER, UE) and is a contribution of the Marine Zooplankton Ecology

338 Group (2017 SGR 87). AA was funded with an FPI fellowship (BES-2015-074092)

339 from the MICINN of Spain.

340

341 Conflicts of Interest. Anna Arias, Erik Selander, Enric Saiz and Albert Calbet

342 declare that they have no conflict of interest.

344 Ethical approval. This article does not contain any studies with animals performed 345 by any of the authors.

346

347 Authors' contributions. AA and AC conceived and designed the experiments. AA

348 performed the experiments. AA, AC, ESL and ESZ participated in the data analysis.

349 ESL contributed reagents and materials. AA, AC and ESZ contributed to the

350 statistical analyses. AA, AC, ESL and ESZ wrote and gave final approval for the 351 publication.

353 Graphics program. All Figures have been elaborated using KaleidaGraph, except for 354 Figure S2 which was elaborated with MATLAB. 


\section{References}

1. Calbet A, Saiz E (2005) The ciliate-copepod link in marine ecosystems. Aquat Microb Ecol 38: 157-167. https://doi.org/10.3354/ame038157

2. Gifford DJ (1991) The protozoan-metazoan trophic link in pelagic ecosystems. J Protozool 38: 81-86. https://doi.org/10.1111/j.1550-7408.1991.tb04806.x

3. Arias A, Saiz E, Calbet A (2017) Diel feeding rhythms in marine microzooplankton: effects of prey concentration, prey condition, and grazer nutritional history. Mar Biol 164: 205. https://doi.org/10.1007/s00227-0173233-7

4. Jakobsen HH, Strom SL (2004) Circadian cycles in growth and feeding rates of heterotrophic protist plankton. Limnol Oceanogr 49: 1915-1922. https://doi.org/10.4319/1o.2004.49.6.1915

5. $\mathrm{Ng}$ WHA, Liu H (2015) Diel variation of the cellular carbon to nitrogen ratio of Chlorella autotrophica (Chlorophyta) growing in phosphorus- and nitrogenlimited continuous cultures. J Phycol 51: 82-92. https://doi.org/10.1111/jpy.12254

6. Ng WHA, Liu H, Zhang S (2017) Diel variation of grazing of the dinoflagellate Lepidodinium sp. and ciliate Euplotes sp. on algal prey: the effect of prey cell properties. J Plankton Res 39: 450-462. https://doi.org/10.1093/plankt/fbx020

7. Strom SL (2001) Light-aided digestion, grazing and growth in herbivorous protists. Aquat Microb Ecol 23: 253-261. https://doi.org/10.3354/ame023253

8. Arias A, Saiz E, Calbet A (2019) Towards an understanding of diel feeding rhythms in marine protists: consequences of light manipulation. Microb Ecol 79: 64-72. https://doi.org/10.1007/s00248-019-01390-y

9. Broglio E, Johansson M, Jonsson PR (2001) Trophic interaction between copepods and ciliates: effects of prey swimming behavior on predation risk. Mar Ecol Prog Ser 220: 179-186. https://doi.org/10.3354/meps220179

10. Lima SL, Dill LM (1990) Behavioral decisions made under the risk of predation: a review and prospectus. Can J Zool 68: 619-640. https://doi.org/10.1139/z90-092

11. Tiselius P, Jonsson P, Verity P (1993) A model evaluation of the impact of food patchiness on foraging strategy and predation risk in zooplankton. Bull Mar Sci 53: 247-264.

12. Titelman J (2001) Swimming and escape behavior of copepod nauplii: implications for predator-prey interactions among copepods. Mar Ecol Prog Ser 213: 203-213. https://doi.org/10.3354/meps213203

13. Bollens S, Frost B (1989) Predator-induced diet vertical migration in a planktonic copepod. J Plankton Res 11: 1047-1065. https://doi.org/10.1093/plankt/11.5.1047

14. Bollens SM, Frost BW (1991) Diel vertical migration in zooplankton: rapid individual response to predators. J Plankton Res 13: 1359-1365. https://doi.org/10.1093/plankt/13.6.1359

15. Selander E, Heuschele J, Nylund GM, Pohnert G, Pavia H, Bjærke O, PenderHealy LA, Tiselius P, Kiørboe T (2016) Solid phase extraction and metabolic profiling of exudates from living copepods. PeerJ 4: e1529. https://doi.org/ doi: 10.7717/peerj.1529

16. Selander E, Kubanek J, Hamberg M, Andersson MX, Cervin G, Pavia H (2015) Predator lipids induce paralytic shellfish toxins in bloom-forming algae. Proc Natl Acad Sci USA 112: 6395-6400. https://doi.org/10.1073/pnas.1420154112 
17. Selander E, Berglund E, Engström P, Berggren F, Eklund J, Harðardóttir S,

22. Anderson SR, Menden-Deuer S (2017). Growth, grazing, and starvation survival in three heterotrophic dinoflagellate species. J Eukaryot Microbiol, 64(2), 213-225.

23. Senft-Batoh CD, Dam HG, Shumway SE, Wikfors GH (2015) A multi-phylum study of grazer-induced paralytic shellfish toxin production in the dinoflagellate Alexandrium fundyense: a new perspective on control of algal toxicity. Harmful Algae, 44, 20-31

24. Tsuda A, Furuya K, Nemoto T (1989). Feeding of micro- and macrozooplankton at the subsurface chlorophyll maximum in the subtropical North Pacific. J Exp Mar Biol Ecol 132, 41-52

25. Selander E, Heuschele J, Nylund GM, Pohnert G, Pavia H, Bjærke O, ... \& Kiørboe T (2016). Solid phase extraction and metabolic profiling of exudates from living copepods. PeerJ, 4, e1529

26. Grebner W, Berglund EC, Berggren F, Eklund J, Harðadóttir S, Andersson MX, Selander E (2018) Induction of defensive traits in marine plankton-new copepodamide structures. Limnol Oceanogr 64: 820-831. https://doi.org/10.1002/lno.11077

27. Calbet A, Saiz E, Irigoien X, Alcaraz M, Trepat I (1999) Food availability and diel feeding rhythms in the marine copepods Acartia grani and Centropages $\begin{array}{lllll}\text { typicus. } & \mathrm{J} \text { Plankton }\end{array}$ https://doi.org/10.1093/plankt/21.5.1009

28. Bollens SM, Stearns DE (1992) Predator-induced changes in the diel feeding cycle of a planktonic copepod. J Exp Mar Biol Ecol 156: 179-186. https://doi.org/10.1016/0022-0981(92)90244-5

29. Kiørboe T, Saiz E, Tiselius P, Andersen KH (2018) Adaptive feeding behavior and functional responses in zooplankton. Limnol Oceanogr 63: 308-321. https://doi.org/10.1002/lno.10632

30. Olivares, M., Calbet, A., \& Saiz, E. (2020). Effects of multigenerational rearing, ontogeny and predation threat on copepod feeding rhythms. Aquatic Ecology, $1-13$. 
31. Hairston NG, Olds EJ (1987) Population differences in the timing of diapause: a test of hypotheses. Oecologia 71: 339-344. https://doi.org/10.1007/BF00378705

32. Jersabek CD, Luger MS, Schabetsberger R, Grill S, Strickler JR (2007) Hang on or run? Copepod mating versus predation risk in contrasting environments. Oecologia 153: 761-773. https://doi.org/10.1007/s00442-007-0768-1

33. Svensson J-E (1997) Fish predation on Eudiaptomus gracilis in relation to clutch size, body size, and sex: a field experiment. Hydrobiologia 344: 155-161. https://doi.org/10.1023/A:1002966614054

34. Hansson L-A (2004) Plasticity in pigmentation induced by conflicting threats from predation and UV radiation. Ecology 85: 1005-1016. https://doi.org/10.1890/02-0525

35. Ringelberg J (1991) Enhancement of the phototactic reaction in Daphnia hyalina by a chemical mediated by juvenile perch (Perca fluviatilis). J Plankton Res 13: 17-25. https://doi.org/10.1093/plankt/13.1.17

36. Tollrian R (1995) Predator-induced morphological defenses: costs, life history shifts, and maternal effects in Daphnia pulex. Ecology 76: 1691-1705. https://doi.org/10.2307/1940703

37. Weider LJ, Pijanowska J (1993) Plasticity of Daphnia life histories in response to chemical cues from predators. Oikos 67: 385-392. https://doi.org/10.2307/3545351

38. Gilbert JJ (1999) Kairomone-induced morphological defenses in rotifers. In: Tollrian, R, Harvell, CD (eds.) The Ecology and Evolution of Inducible Defenses. Princeton University Press, Princeton, New Jersey, pp. 127-141

39. Selander E, Thor P, Toth G, Pavia H (2006) Copepods induce paralytic shellfish toxin production in marine dinoflagellates. Proc R Soc B 273: 1673-1680. https://doi.org/10.1098/rspb.2006.3502

40. Jakobsen HH (2001) Escape response of planktonic protists to fluid mechanical signals. Mar Ecol Prog Ser 214: 67-78. https://doi.org/10.3354/meps214067

41. Jonsson PR, Tiselius P (1990) Feeding behaviour, prey detection and capture efficiency of the copepod Acartia tonsa feeding on planktonic ciliates. Mar Ecol Prog Ser 35-44. https://doi.org/10.3354/meps060035

42. Lindholm T (1985) Mesodinium rubrum - a unique photosynthetic ciliate. Adv Aquat Microbiol 3: 1-48.

43. Fenchel T, Hansen PJ (2006) Motile behaviour of the bloom-forming ciliate Mesodinium rubrum. Mar Biol Res 2: 33-40. https://doi.org/10.1080/17451000600571044

44. Urban MC (2007) The growth-predation risk trade-off under a growing gapelimited predation threat. Ecology 88: 2587-2597. https://doi.org/10.1890/061946.1

45. Pauwels K, Stoks R, De Meester L (2010) Enhanced anti-predator defence in the presence of food stress in the water flea Daphnia magna. Funct Ecol 24: 322-329. https://doi.org/10.1111/j.1365-2435.2009.01641.x

46. Rose R, Warne MSJ, Lim R (2001) Factors associated with fish modify life history traits of the cladoceran Ceriodaphnia cf. dubia. J Plankton Res 23: 1117. https://doi.org/10.1093/plankt/23.1.11

47. Watts PC, Martin LE, Kimmance SA, Montagnes DJ, Lowe CD (2011) The distribution of Oxyrrhis marina: a global disperser or poorly characterized endemic? J Plankton Res 33: 579-589. https://doi.org/10.1093/plankt/fbq148 
48. Begun AA, Orlova TY, Selina MS (2004). A "bloom" in the water of Amursky Bay (Sea of Japan) caused by the dinoflagellate Oxyrrhis marina Dujardin, 1841. Russ J Mar Biol 30(1), 51-55.

49. Johnson, M. P. (2000). Physical control of plankton population abundance and dynamics in intertidal rock pools. In Island, Ocean and Deep-Sea Biology (pp. 145-152). Springer, Dordrecht.

50. Berge T, Poulsen LK, Moldrup M, Daugbjerg N, Hansen PJ (2012) Marine microalgae attack and feed on metazoans. ISME J 6: 1926-1936. https://doi.org/10.1038/ismej.2012.29

51. Rasmussen SA, Binzer SB, Hoeck C, Meier S, De Medeiros LS, Andersen NG, Place A, Nielsen KF, Hansen PJ, Larsen TO (2017) Karmitoxin: an aminecontaining polyhydroxy-polyene toxin from the marine dinoflagellate Karlodinium armiger. J Nat Prod 80: 1287-1293. https://doi.org/10.1021/acs.jnatprod.6b00860

52. Bergkvist J, Selander E, Pavia H (2008) Induction of toxin production in dinoflagellates: the grazer makes a difference. Oecologia 156: 147-154. https://doi.org/10.1007/s00442-008-0981-6

53. Wohlrab S, Iversen MH, John U (2010) A molecular and co-evolutionary context for grazer induced toxin production in Alexandrium tamarense. PLoS One 5(11): e15039. https://doi.org/10.1371/journal.pone.0015039

54. Xu J, Kiørboe T (2018) Toxic dinoflagellates produce true grazer deterrents. Ecology 99(10): 2240-2249. https://doi.org/10.1002/ecy.2479

55. Armengol, L., Calbet, A., Franchy, G., Rodríguez-Santos, A., and HernándezLeón, S. 2019. Planktonic food web structure and trophic transfer efficiency along a productivity gradient in the tropical and subtropical Atlantic Ocean. Scientific Reports, 9(1):2044.

56. Arias A, Saiz E, Tiselius P, Calbet A (2020). Trophic interactions and diel feeding rhythms of microzooplankton in a productive Swedish Fjord. ICES J. Mar. Sci. 
Table 1. Prey (Rhodomonas salina) and grazer concentrations (cells $\mathrm{mL}^{-1}$ ) used in the feeding experiments. The period of time the grazer cultures were maintained under laboratory conditions is also shown.

Table 2. Initial, final and average effective concentrations of copepodamides during the feeding incubations. The half-life (T1/2) of the copepodamides is also provided.

Table 3. Total daily ingestion rates (day+night sum; prey $\mu \mathrm{m}^{3}$ grazer $^{-1}$ day $^{-1}$ ) of the studied grazers under the different copepodamide concentrations. The percentage of variation with respect to the control treatments is also provided. Data from Experiment 1 and Experiment 2 are presented separately. ANOVA Dunnett test p-values are shown. n.s. indicates no significant differences.

Fig. 1 Illustration of microzooplankton feeding during the day and during the night, when they are exposed to increased threat of predation by copepods.

Fig. 2 Diel feeding rhythms, as the quotient between day and night ingestion rates, of $S$. arenicola, $M$. rubrum, $G$. dominans, $K$. armiger and $O$. marina as a function of the time in culture since isolation. All day ingestion rates were significantly higher than the night ingestion rates ( $\mathrm{t}$-test, $p<0.01$ ). Dashed lines indicate the value of equal day and night ingestion rates (i.e., non-existence of diel feeding rhythm), and error bars show the standard deviation.

Fig. 3 (a) Temporal evolution in the diel feeding rhythm of the ciliate $S$. arenicola, expressed as the quotient between day and night ingestion rates, from isolation (October 2017) until December 2018. Asterisks indicate significant differences between day and night ingestion rates (t-test, $p<0.001$ ) (b) Recovery of the diel feeding rhythm in S. arenicola, after 19 and 20 months from isolation, as a function of copepodamide effective concentrations. Yellow and green symbols denote two independent experiments. Asterisks indicate significant differences between copepodamide treatments relative to the control (t-test, $p<0.05$ ). Dashed lines indicate the values of equal day and night ingestion rates (i.e., nonexistence of diel feeding rhythm). Error bars show the standard errors.

Fig. 4 Diel feeding rhythms, as the quotient between day and night ingestion rates, of (a) M. rubrum, (b) G. dominans, (c) K. armiger, and (d) O. marina as a function of copepodamide effective concentrations. Yellow and green denote two independent experiments. Asterisks indicate significant differences between copepodamide treatments relative to the control ( $\mathrm{t}$-test, $* p<0.05$ ). Dashed lines indicate the values of equal day and night ingestion rates (i.e., non-existence of diel feeding rhythm). Error bars show the standard errors.

Fig. S1 Ingestion rate of the ciliate Strombidium arenicola $\left(\mu \mathrm{m}^{3}\right.$ grazer $\left.^{-1} \mathrm{~h}^{-1}\right)$ as a function of prey concentration $\left(\mu \mathrm{m}^{3} \mathrm{~mL}^{-1}\right)$. Error bars show standard error.

Fig. S2 Effective concentration (nM) of copepodamides during 10h incubation. Closed circles represent the average data from the sampling time points and shaded area is the error interval (standard deviation).

Table S1 Day and night ingestion rates (in terms of prey volume ingested, $\mu \mathrm{m}^{3}$ grazer $^{-1}$ hour $^{-1}$ ) for each of the studied grazer species as a function of copepodamides treatments (Control, $0.6 \mathrm{pM}$ and $6 \mathrm{pM}$ ). Rates are differentiated between Experiment 1 and Experiment 2. Average \pm standard error are shown. $p$-values from one-way ANOVA followed by a Dunnet's test are presented to show the significance level of each copepodamides treatment with respect to the correspondent control in each phase (day and night). 


\section{Table 1}

\begin{tabular}{|c|c|c|c|}
\hline Grazer & $\begin{array}{l}\text { Time since } \\
\text { isolation }\end{array}$ & $\begin{array}{l}\text { Prey concentration } \\
\quad\left(\text { cell } \mathrm{mL}^{-1}\right)\end{array}$ & $\begin{array}{c}\text { Grazer concentration } \\
\left(\text { cell } \mathbf{m L}^{-1}\right)\end{array}$ \\
\hline \multirow[t]{4}{*}{ Strombidium arenicola } & 6 months & $46079-48952$ & $175-343$ \\
\hline & 10 months & $75091-77118$ & $259-387$ \\
\hline & 19 months & $78094-80915$ & $206-388$ \\
\hline & 20 months & $81544-84929$ & $272-462$ \\
\hline Mesodinium rubrum & 8 years & $10570-12860$ & $1510-2988$ \\
\hline Gyrodinium dominans & 6 years & $100700-110500$ & $3000-3580$ \\
\hline Karlodinium armiger & 4 years & $100000-111800$ & $6130-7500$ \\
\hline Oxyrrhis marina & 22 years & $140010-160500$ & $1705-2360$ \\
\hline
\end{tabular}


Table 2

\begin{tabular}{cccc}
\hline $\begin{array}{c}\text { Initial } \\
\text { concentration } \\
(\mathrm{pM})\end{array}$ & $\begin{array}{c}\text { Final } \\
\text { concentration } \\
(\mathrm{pM})\end{array}$ & $\begin{array}{c}\text { Average effective } \\
\text { concentration }(\mathrm{pM})\end{array}$ & $\mathrm{T}_{1 / 2}(\mathrm{~h})$ \\
\hline 1.4 & 0.2 & 0.6 & 6.2 \\
18 & 2 & 6 & 3.2 \\
\hline
\end{tabular}




\section{Table 3}

\begin{tabular}{|c|c|c|c|c|c|c|c|}
\hline \multirow[b]{2}{*}{ Species } & \multirow[b]{2}{*}{ Treatment } & \multicolumn{3}{|c|}{ EXPERIMENT 1} & \multicolumn{3}{|c|}{ EXPERIMENT 2} \\
\hline & & $\begin{array}{c}\text { Ingestion } \\
(\operatorname{avg} \pm \mathrm{SE})\end{array}$ & $\begin{array}{c}\% \% \\
\text { variation }\end{array}$ & $p$ & $\begin{array}{c}\text { Ingestion } \\
(\operatorname{avg} \pm \mathrm{SE})\end{array}$ & $\begin{array}{c}\% \\
\text { variation }\end{array}$ & $p$ \\
\hline \multirow{3}{*}{ S. arenicola } & Control & $51229 \pm 1782$ & 0 & - & $26285 \pm 463$ & 0 & - \\
\hline & 1.4 & $46374 \pm 2312$ & -9.5 & n.s. & $25422 \pm 751$ & -3.3 & n.s. \\
\hline & 18 & $44325 \pm 443$ & -13.5 & $<0.05$ & $24168 \pm 392$ & -8.1 & n.s. \\
\hline \multirow{3}{*}{ M. rubrum } & Control & $228 \pm 0.7$ & 0 & - & $732 \pm 14$ & 0 & - \\
\hline & 1.4 & $315 \pm 9.1$ & 38.1 & $<0.001$ & $817 \pm 16$ & 11.6 & $<0.05$ \\
\hline & 18 & $275 \pm 7.8$ & 20.6 & $<0.01$ & $892 \pm 20$ & 21.8 & $<0.001$ \\
\hline \multirow{3}{*}{ G. dominans } & Control & $6078 \pm 68$ & 0 & - & $7307 \pm 91$ & 0 & - \\
\hline & 1.4 & $6718 \pm 53$ & 10.5 & $<0.001$ & $8061 \pm 35$ & 10.3 & $<0.001$ \\
\hline & 18 & $6997 \pm 43$ & 15.1 & $<0.001$ & $7704 \pm 17$ & 5.4 & $<0.01$ \\
\hline \multirow{3}{*}{ K. armiger } & Control & $2448 \pm 46$ & 0 & - & $1807 \pm 14$ & 0 & - \\
\hline & 1.4 & $2305 \pm 58$ & -5.8 & n.s. & $1753 \pm 12$ & -3.0 & n.s. \\
\hline & 18 & $2286 \pm 23$ & -6.6 & n.s. & $2118 \pm 23$ & 17.2 & $<0.001$ \\
\hline \multirow{3}{*}{ O.marina } & Control & $13305 \pm 116$ & 0 & - & $17035 \pm 77$ & 0 & - \\
\hline & 1.4 & $14442 \pm 253$ & 8.5 & $<0.01$ & $17749 \pm 81$ & 4.2 & $<0.05$ \\
\hline & 18 & $13509 \pm 54$ & 1.5 & $n . s$. & $18849 \pm 192$ & 11 & $<0.001$ \\
\hline
\end{tabular}




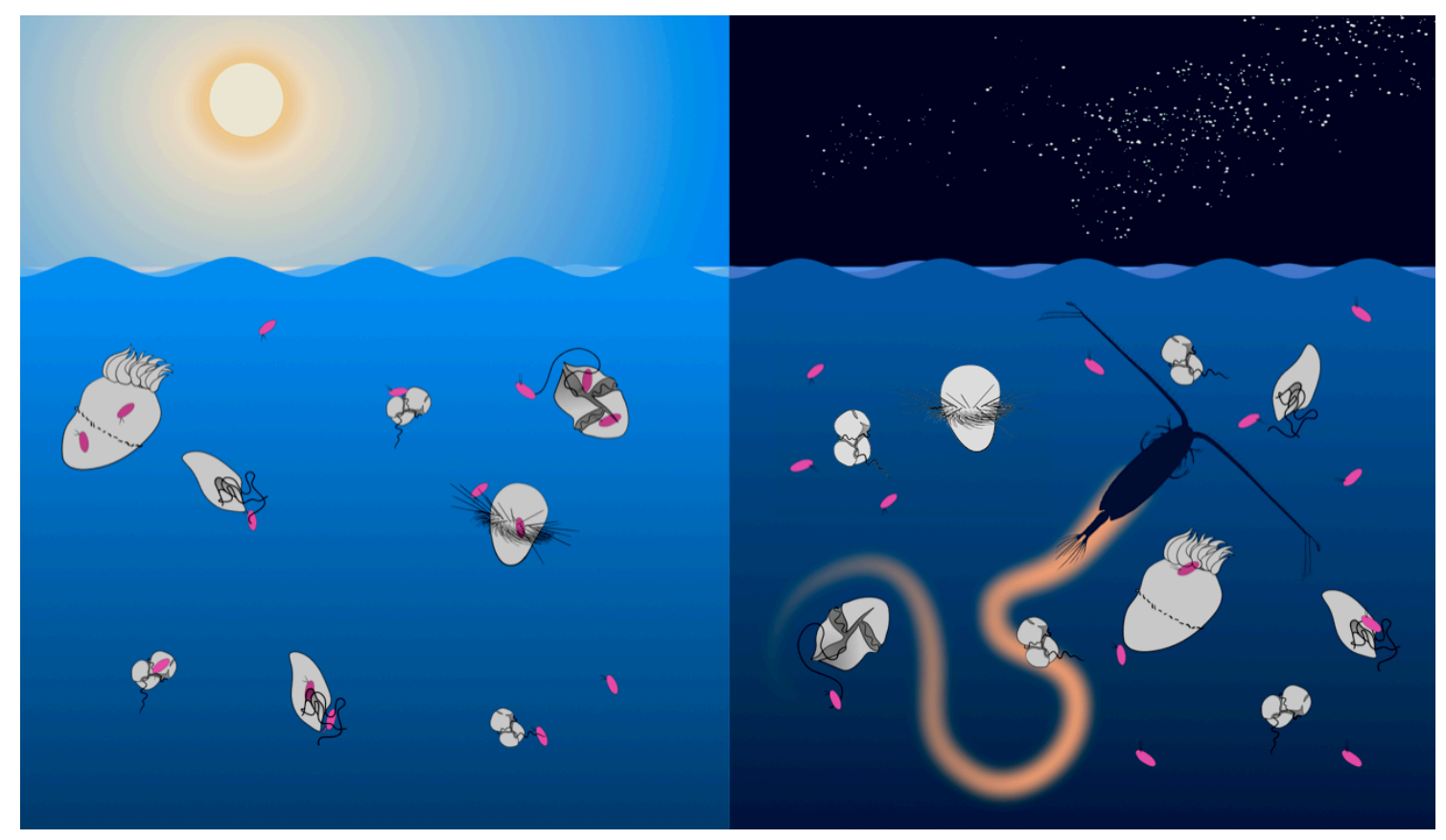

Figure 1 


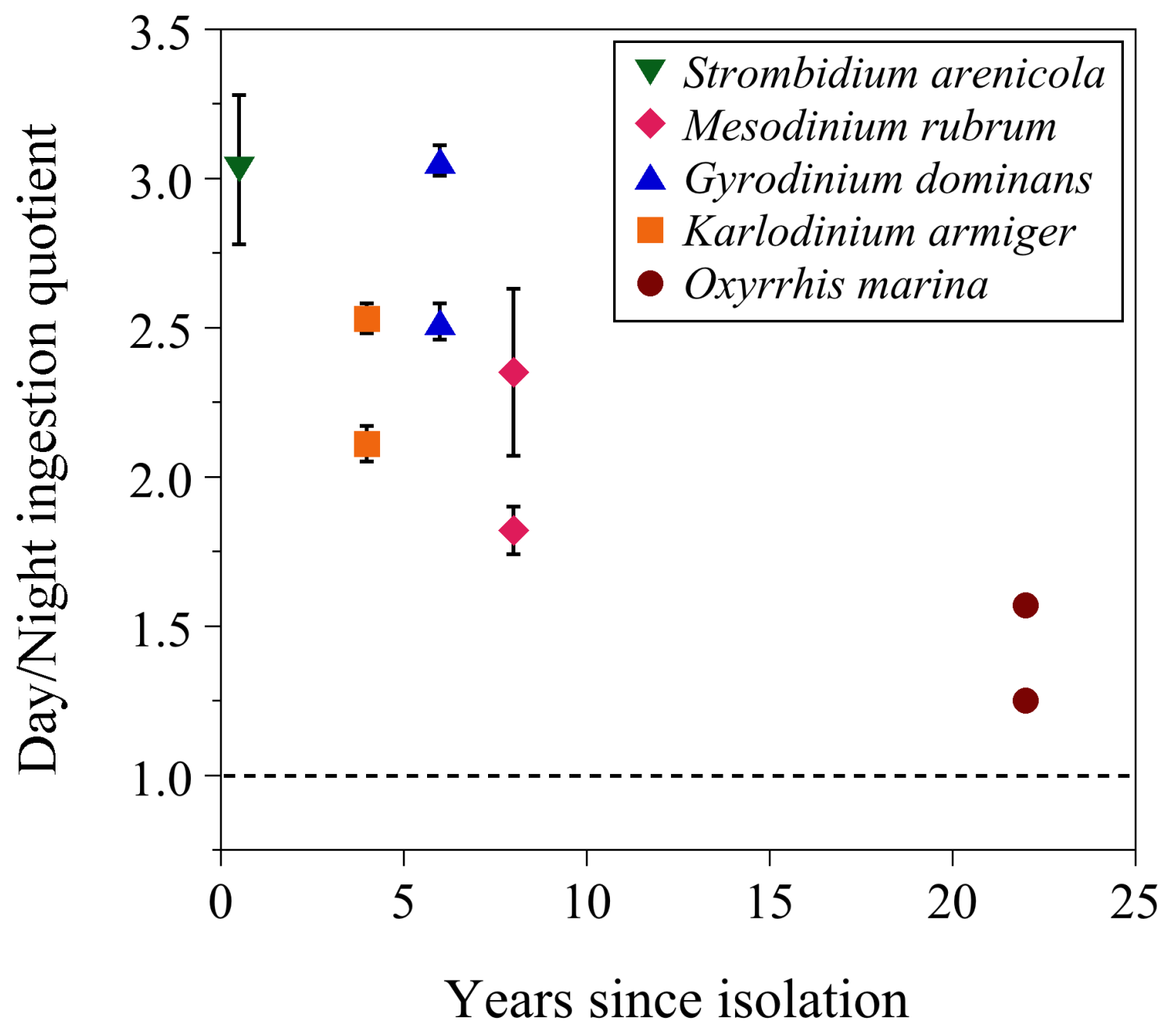

Figure 2 

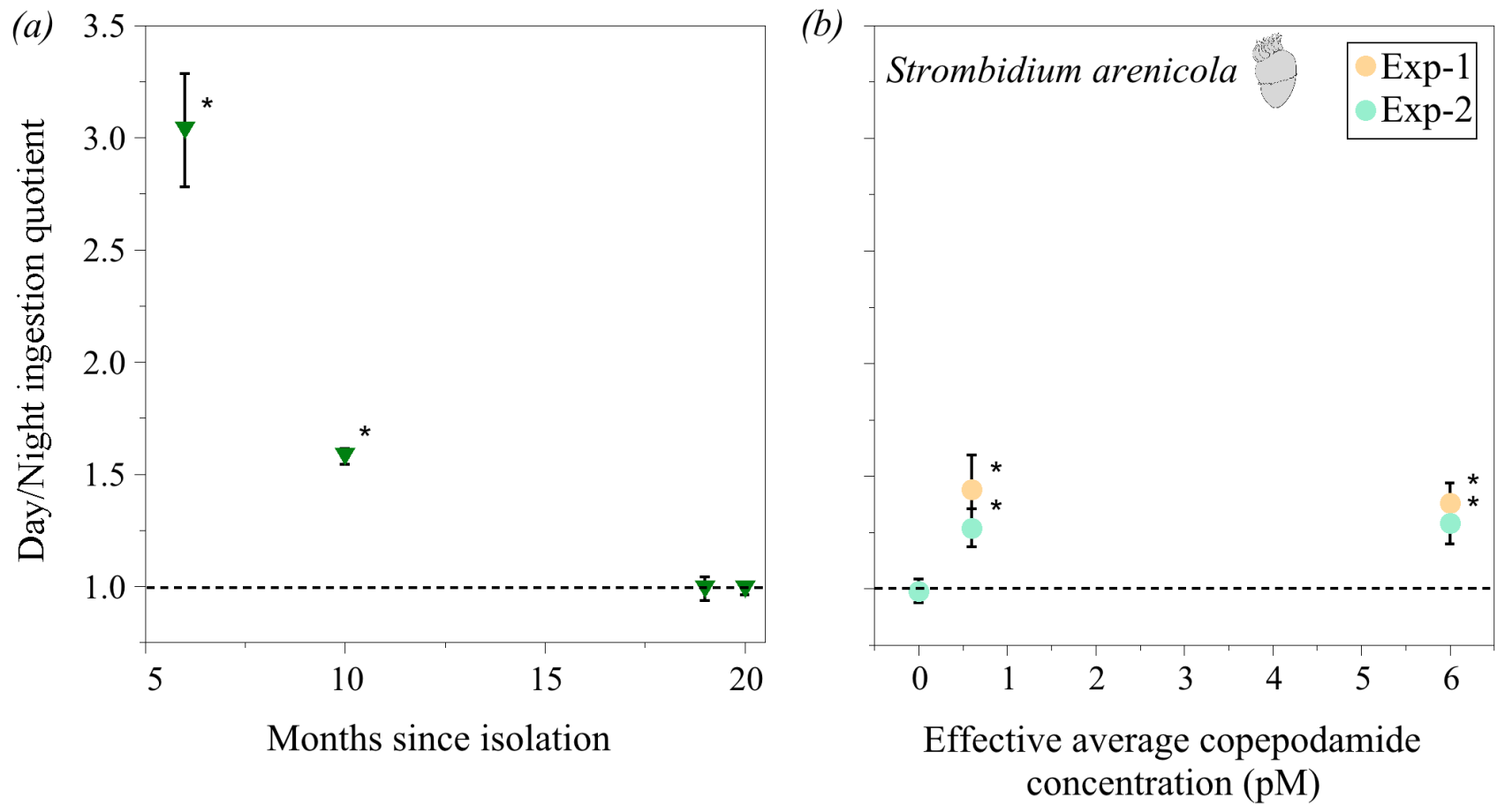

Figure 3 

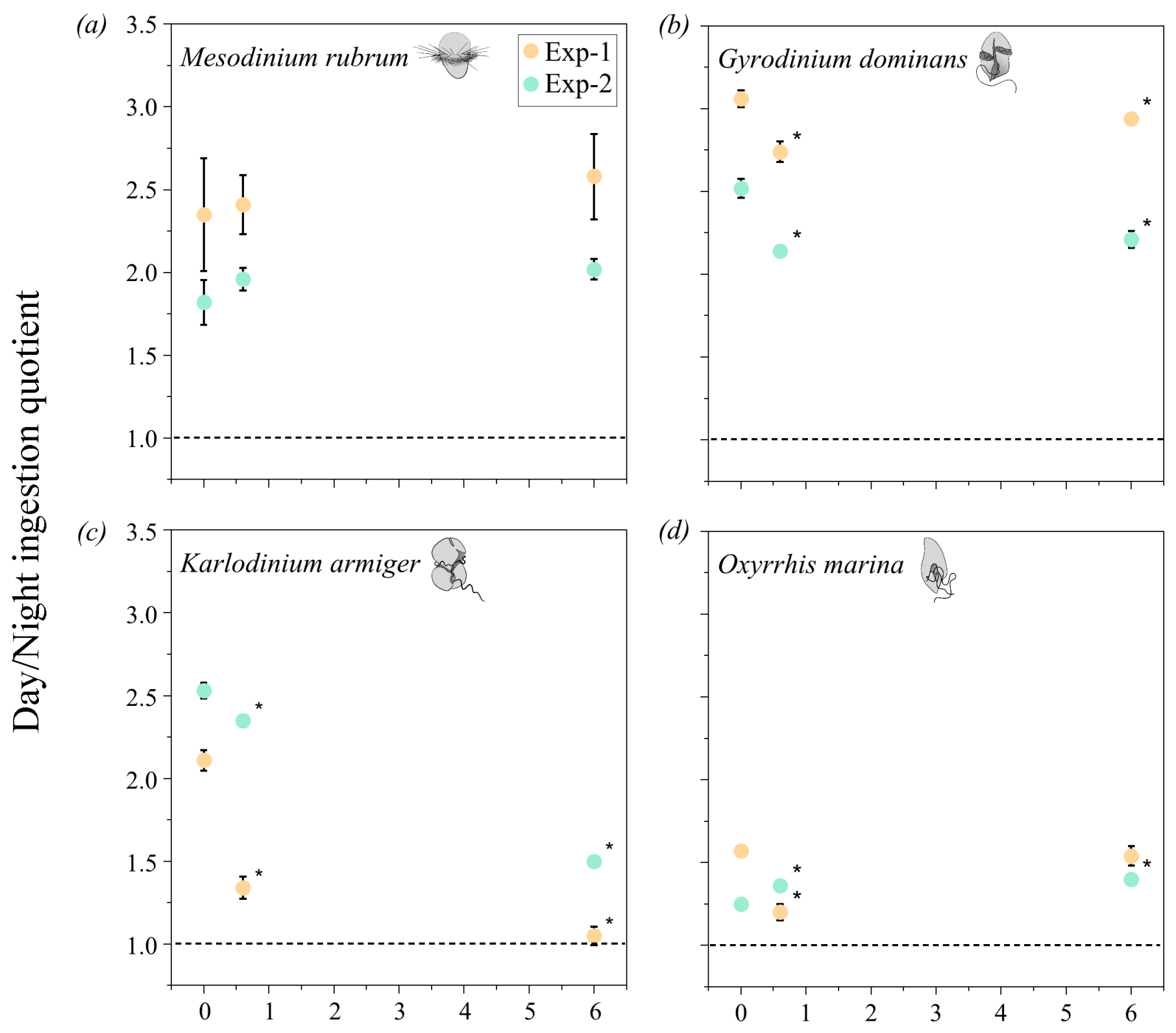

Effective average copepodamide concentration (pM)

\section{Figure 4}




\section{Microbial Ecology}

Predator chemical cue effects on the diel feeding behaviour of marine protists

Anna Arias $^{1 *}$, Erik Selander ${ }^{2}$, Enric Saiz $^{1}$, Albert Calbet $^{1}$

${ }^{1}$ Institut de Ciències del Mar (ICM-CSIC), Passeig Marítim de la Barceloneta 37-49, 08003 Barcelona, Spain

${ }^{2}$ Department of Marine Sciences, University of Gothenburg, Box 461, SE-450 30 Göteborg, Sweden

E-mail address of the corresponding author: arias@icm.csic.es 
a) Functional response of the recent isolated ciliate Strombidium arenicola

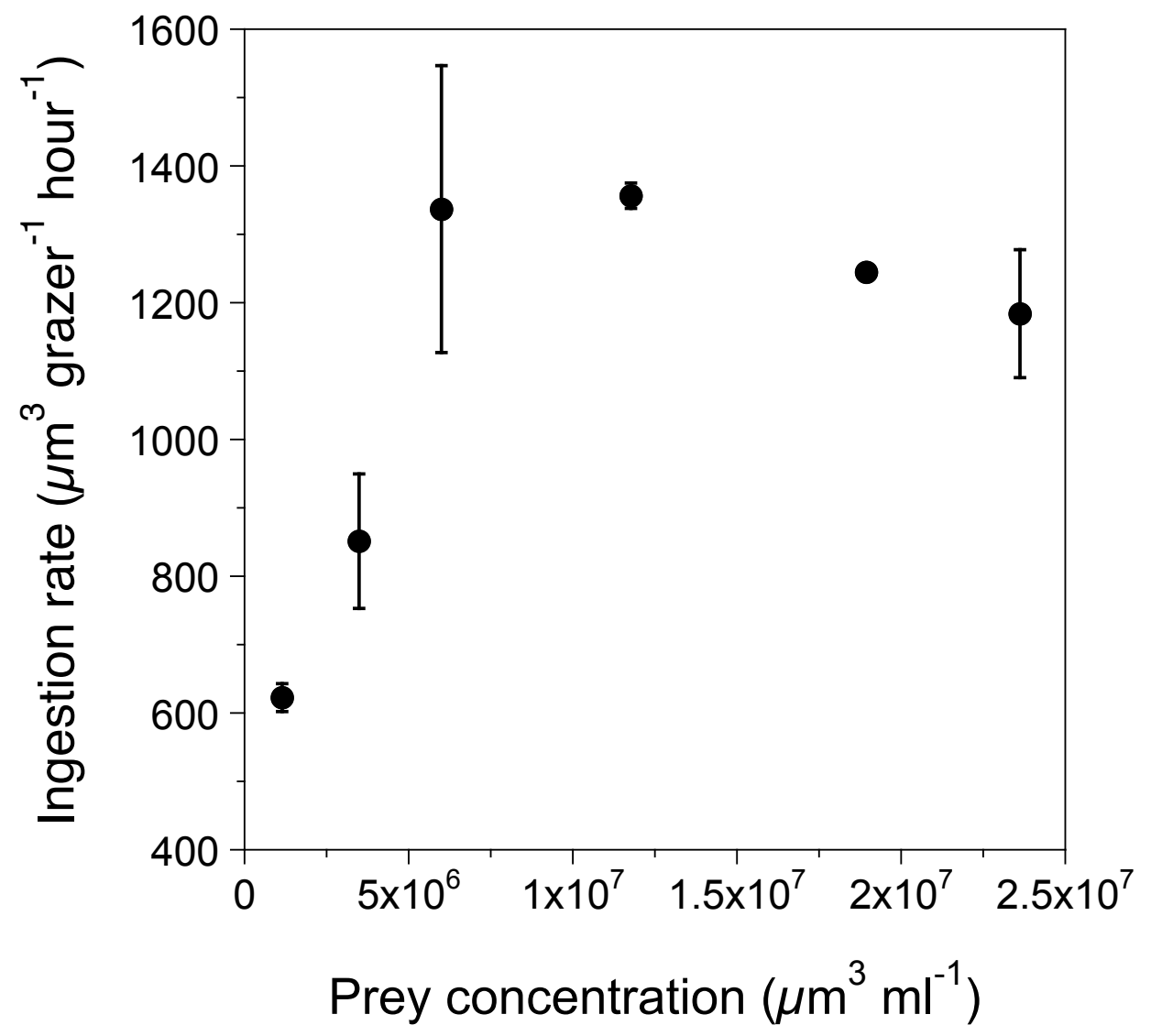

Figure S1 


\section{b) Determination of copepodamides concentrations}

As copepodamides are surface-active and degrade over time, a preliminar test was carried out to measure the effective concentrations in the experiments over time. Copepodamides were extracted from freeze-dried Calanus finmarchicus, both male and female, through a series of chemical separation steps (see Selander et al., 2015 for details). The experimental procedures to assess the losses of copepodamide were performed in identical conditions to that of the feeding experiments (see below section).

Four sets of suspensions in FSW medium were prepared with mixtures of the desired prey and grazer concentrations, with copepodamides added at the following nominal concentrations: 0 (only adding methanol, the diluent), 0.01, 0.1 and $1 \mathrm{nM}$. Each suspension was split into twelve $72 \mathrm{ml}$ polyethylene culture flasks, to get three replicates per each copepodamide concentration at every sampling time: $t=0$ (initial samples), 2, 5, and 10 (final samples) hours. Flasks were all incubated on a plankton wheel (0.2 r.p.m) at $19 \pm 1^{\circ} \mathrm{C}$, and an irradiation of $90 \mu \mathrm{E} \mathrm{m}^{-2} \mathrm{~s}^{-1}$. The triplicate samples from each concentration removed at every sampling time were loaded onto solid-phase extraction (SPE) columns (Evolute Express ABN, 100 mg, 3ml, Biotage). The columns were de-salted with 1 column volume MilliQ water and the compounds eluted into $3 \mathrm{ml}$ methanol. The methanol evaporated and the copepodamides were then resolved in a small $(80 \mu \mathrm{l})$ volume before analysis on an Agilent 1260 Infinity HPLC system connected to an Agilent 6410 Triple Quad LC/MS (see Selander et al., 2015 for further details). 


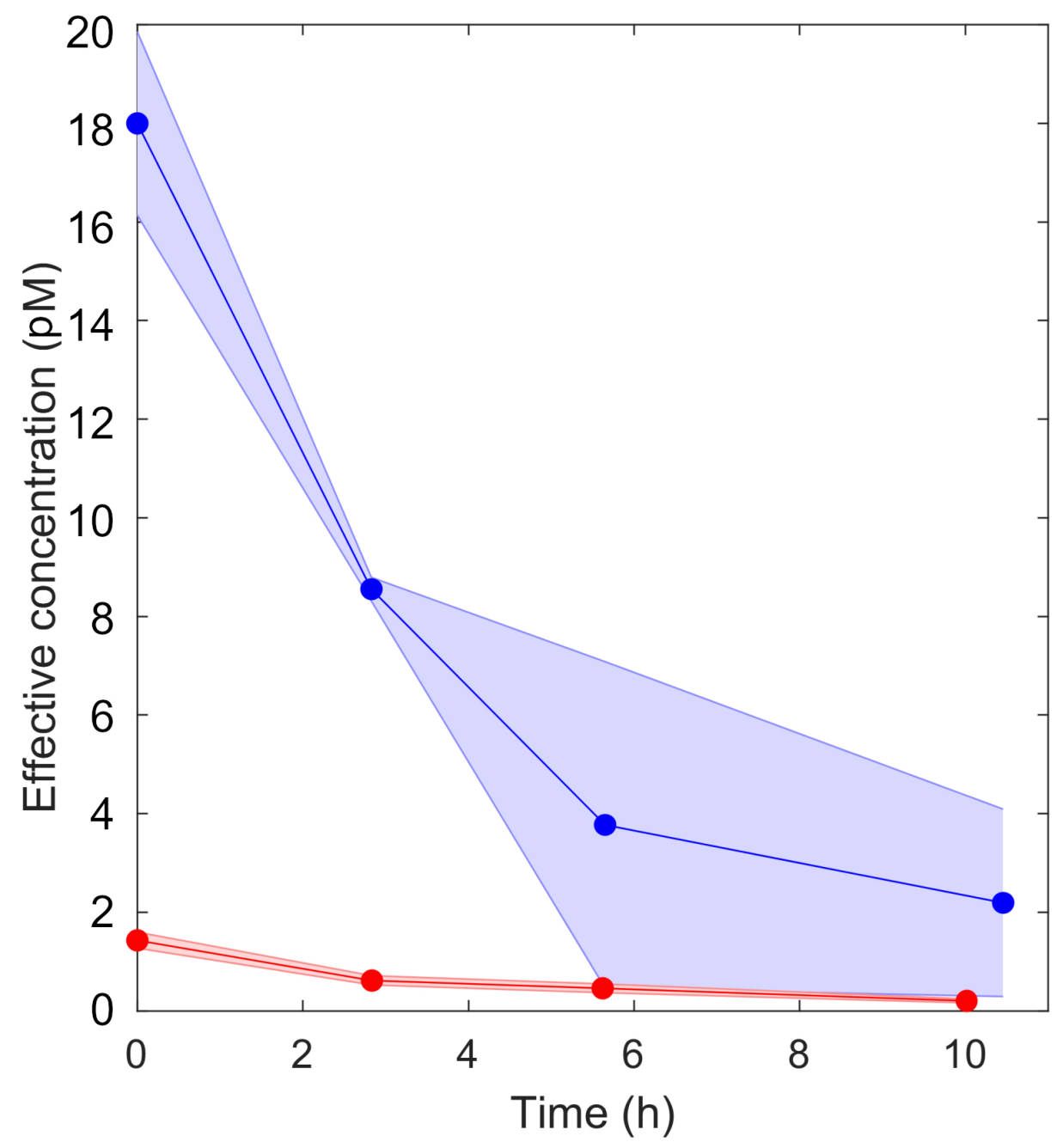

Figure S2 


\section{Table S1}

c) Total daily ingestions of the target grazers

\begin{tabular}{|c|c|c|c|c|c|c|c|c|c|c|c|c|c|c|c|c|c|c|c|c|}
\hline \multirow[b]{3}{*}{ Species } & \multicolumn{10}{|c|}{ EXPERIMENT 1} & \multicolumn{10}{|c|}{ EXPERIMENT 2} \\
\hline & \multicolumn{2}{|c|}{$\begin{array}{c}\text { Control } \\
\text { (Methanol) }\end{array}$} & \multicolumn{4}{|c|}{$0.6 \mathrm{pM}$} & \multicolumn{4}{|c|}{$6 \mathrm{pM}$} & \multicolumn{2}{|c|}{$\begin{array}{c}\text { Control } \\
\text { (Methanol) }\end{array}$} & \multicolumn{4}{|c|}{$0.6 \mathrm{pM}$} & \multicolumn{4}{|c|}{$6 \mathrm{pM}$} \\
\hline & $\begin{array}{l}\text { Day } \\
\pm \text { SE }\end{array}$ & $\begin{array}{c}\text { Night } \\
\pm \mathbf{S E}\end{array}$ & $\begin{array}{l}\text { Day } \\
\pm \text { SE }\end{array}$ & p-value & $\begin{array}{c}\text { Night } \\
\pm \text { SE }\end{array}$ & p-value & $\begin{array}{l}\text { Day } \\
\pm \text { SE }\end{array}$ & p-value & $\begin{array}{l}\text { Night } \\
\pm \mathbf{S E}\end{array}$ & p-value & $\begin{array}{l}\text { Day } \\
\pm \text { SE }\end{array}$ & $\begin{array}{c}\text { Night } \\
\pm \mathbf{S E}\end{array}$ & $\begin{array}{l}\text { Day } \\
\pm \text { SE }\end{array}$ & p-value & $\begin{array}{c}\text { Night } \\
\pm \text { SE }\end{array}$ & p-value & $\begin{array}{l}\text { Day } \\
\pm \text { SE }\end{array}$ & p-value & $\begin{array}{c}\text { Night } \\
\pm \mathrm{SE}\end{array}$ & p-value \\
\hline $\begin{array}{l}\text { S. arenícola } \\
\text { (Oct 17) }\end{array}$ & $\begin{array}{l}810.9 \\
\pm 27.7\end{array}$ & $\begin{array}{l}267.4 \\
\pm 20.4\end{array}$ & & & & & & & & & & & & & & & & & & \\
\hline $\begin{array}{l}\text { S. arenícola } \\
\text { (Feb 18) }\end{array}$ & $\begin{array}{c}2590.5 \\
\pm 55.4\end{array}$ & $\begin{array}{l}1640.2 \\
\pm 12.7\end{array}$ & & & & & & & & & & & & & & & & & & \\
\hline $\begin{array}{l}\text { S. arenícola } \\
\text { (Nov-Dec } 18)\end{array}$ & $\begin{array}{c}2120.6 \\
\pm 22.2\end{array}$ & $\begin{array}{l}2144.5 \\
\pm 111.6\end{array}$ & $\begin{array}{c}2347.7 \\
\pm 97.4\end{array}$ & n.s. & $\begin{array}{l}1635.5 \\
\pm 161.9\end{array}$ & $<0.05$ & $\begin{array}{c}2199.1 \\
\pm 83.8\end{array}$ & n.s. & $\begin{array}{l}1595.3 \\
\pm 83.4\end{array}$ & $<0.05$ & $\begin{array}{l}1087.9 \\
\pm 22.0\end{array}$ & $\begin{array}{l}1100.4 \\
\pm 17.8\end{array}$ & $\begin{array}{l}1206.0 \\
\pm 52.7\end{array}$ & n.s. & $\begin{array}{l}953.7 \\
\pm 48.3\end{array}$ & n.s. & $\begin{array}{l}1160.7 \\
\pm 40.0\end{array}$ & n.s. & $\begin{array}{l}897.2 \\
\pm 55.2\end{array}$ & $<0.05$ \\
\hline M. rubrum & $\begin{array}{l}14.3 \\
\pm 0.9\end{array}$ & $\begin{array}{c}6.1 \\
\pm 0.6\end{array}$ & $\begin{array}{l}19.9 \\
\pm 0.3\end{array}$ & $<0.001$ & $\begin{array}{c}8.3 \\
\pm 0.5\end{array}$ & $<0.05$ & $\begin{array}{l}17.8 \\
\pm 0.2\end{array}$ & $<0.01$ & $\begin{array}{c}6.9 \\
\pm 0.5\end{array}$ & n.s. & $\begin{array}{l}41.4 \\
\pm 0.4\end{array}$ & $\begin{array}{l}22.7 \\
\pm 1.0\end{array}$ & $\begin{array}{l}47.7 \\
\pm 1.4\end{array}$ & $<0.01$ & $\begin{array}{l}24.3 \\
\pm 0.4\end{array}$ & n.s. & $\begin{array}{l}52.7 \\
\pm 0.9\end{array}$ & $<0.001$ & $\begin{array}{l}26.0 \\
\pm 0.8\end{array}$ & $<0.05$ \\
\hline O. marina & $\begin{array}{l}702.4 \\
\pm 10.0\end{array}$ & $\begin{array}{l}448.7 \\
\pm 1.3\end{array}$ & $\begin{array}{l}666.8 \\
\pm 24.3\end{array}$ & n.s. & $\begin{array}{l}555.3 \\
\pm 9.2\end{array}$ & $<0.001$ & $\begin{array}{l}706.8 \\
\pm 20.7\end{array}$ & n.s. & $\begin{array}{l}460.1 \\
\pm 11.0\end{array}$ & n.s. & $\begin{array}{l}803.5 \\
\pm 9.2\end{array}$ & $\begin{array}{c}642.9 \\
\pm 1.2\end{array}$ & $\begin{array}{l}873.0 \\
\pm 10.2\end{array}$ & $<0.01$ & $\begin{array}{l}644.2 \\
\pm 11.5\end{array}$ & n.s. & $\begin{array}{c}941.4 \\
\pm 6.2\end{array}$ & $<0.0001$ & $\begin{array}{l}673.9 \\
\pm 10.8\end{array}$ & n.s. \\
\hline K. armiger & $\begin{array}{l}147.2 \\
\pm 4.1\end{array}$ & $\begin{array}{l}69.7 \\
\pm 0.7\end{array}$ & $\begin{array}{l}112.9 \\
\pm 5.4\end{array}$ & $<0.01$ & $\begin{array}{l}84.0 \\
\pm 1.2\end{array}$ & $<0.0001$ & $\begin{array}{l}97.8 \\
\pm 4.8\end{array}$ & $<0.001$ & $\begin{array}{l}93.5 \\
\pm 2.0\end{array}$ & $<0.0001$ & $\begin{array}{l}116.4 \\
\pm 1.9\end{array}$ & $\begin{array}{l}45.9 \\
\pm 0.5\end{array}$ & $\begin{array}{l}109.9 \\
\pm 0.8\end{array}$ & $<0.05$ & $\begin{array}{l}46.7 \\
\pm 0.3\end{array}$ & n.s. & $\begin{array}{l}109.7 \\
\pm 1.2\end{array}$ & $<0.05$ & $\begin{array}{l}73.0 \\
\pm 0.8\end{array}$ & $<0.0001$ \\
\hline
\end{tabular}

